\title{
The effectiveness of technology learning centers in developing some creative-thinking skills for hearing- impaired students in middle school.
}

\section{Prof. Maher Ismail Sabry}

Professor of Curriculum and Pedagogy in Science, Former Chair of the Department of Curriculum, Pedagogy and Educational Technology, Faculty of Education, University of Benha DR. Reda Abdul-Qader Darwish Assistant Professor (Emeritus) of Curriculum and Pedagogy in Science, Faculty of Education, University of Benha Amira Muhammad Zaki Fathallah Assistant Lecturer Department of Curriculum and Pedagogy, Chemistry Teaching Methods

\section{Abstract:}

7 The aim of the research is to identify the effectiveness of technology learning centres in

1 developing some creative thinking skills among 8 deaf middle schoolers (1st grade). The researcher used the one-group quasi-experimental designs in which both groups were pretested and post tested. The prescribed environmental unit for first-grade middle school students was taught in the first semester using technology learning centers. Torrence Test of Creative Thinking (Figures -Image B) was administered to participants. There is a statistically significant difference at the 0.01 level between the average levels of hearing-impaired students in the first year of the middle grades in favor of the posttest.

Keywords: Technology learning centers - creative thinking skills - hearing impaired.

\section{Introduction:}

Creative thinking skills are crucial skills to develop for the hearing impaired learners in the twenty-first century, being prerequisite for scientific progress that may enable the hearing impaired to learn and face the challenges facing them in the future. 
The hearing-impaired person faces many problems due to the negative impact on his interaction and communication with others, and on the skills he possesses, which qualify him to continue studying and working. Therefore, teaching approaches and strategies should be used in a way that suit the characteristics of the hearing impaired, their needs, the nature of their disability and contribute to their education and rehabilitation. (Muhammad and Amer, 2008, 195)

Pchenitchnaia (2007,6) and Ballinger $(2011,3)$ mentioned that learning centers allow students to acquire knowledge, see concepts and skills in different ways and methods in a way that suits the individual differences.

Providing scientific material and richer activities, technology represents a tool for diving deep into the subjects, especially science. The role of technology depends not only on the acquisition of knowledge, but also on the acquisition of basic skills of importance adopting the logic of the "era of information explosion" .

Therefore, attention must be paid to introducing technology in teaching science, whether using technological devices in teaching science, or using educational programs. (Riyadh, 2000, 641).

As a result of the opportunities offered by learning centers and the use of technology in the teaching and learning process, the employment of technology within learning centers can contribute to the development of many skills necessary for the hearing impaired in the preparatory stage, including creative thinking skills. 


\section{Making sense of the problem}

The development of creative thinking skills is one of the most important outputs of learning science in the twenty-first century. Through these skills, the hearing impaired can learn a lot of competences through experience, discovery, application, and modification of ideas and they can express themselves creatively.

Many previous studies have emphasized the need to develop creative thinking skills for the hearing impaired. Among these studies are Issa study (2004), Al-Qatawi Study (2012), Flores \& Rumjanek Study (2015), and Abdullah Study (2017).

Despite the importance of these skills for the hearing impaired, the science curriculum provided for them does not contribute to developing these skills. They are curricula drawn from the general education curricula with some modifications represented in deleting some subjects presented to the hearing impaired who are two years older than the ordinary learners, in addition to their lack of activities and illustrations. Also, the teacher does not care much about using teaching methods and strategies to develop thinking skills among his hearingimpaired students, as he is mostly interested in communicating the education message to them, which hinders the development of their creative thinking skills.

Based on the importance of creative thinking skills as one of the skills needed for the hearing impaired in the twenty-first century, and the inadequacy of the teaching methods used to develop these skills, the current research seeks to verify the effectiveness of technology 
learning centers in developing creative thinking skills for hearing impaired students in the first preparatory grade.

\section{Research problem}

The research problem was determined by the need of the hearing impaired for creative thinking skills as they are necessary to cope with the requirements of the twenty-first century, and to the inadequacy of the teaching methods used to develop those skills. To address this problem, the current research seeks to answer the following main question:

What is the effectiveness of technological learning centers in developing creative thinking skills among students with hearing impairment in middle school?

\section{Research objective:}

The aim of the research was to verify the effectiveness of technology learning centers in developing creative thinking skills of hearing impaired prep students.

\section{Research Importance:}

The importance of the research was as follows:

- Providing a guide for the teacher explaining the mechanism of using technology learning centers in teaching the environment unit prescribed for technical middle school first graders, first semester. This guide may be useful for researchers and for those interested in developing curricula of the hearing impaired.

- Offering a set of electronic activities that develop creative thinking skills. These activities may benefit researchers, curriculum designers, and teachers in 
developing creative thinking skills of hearing impaired students in the preparatory stage.

\section{Research Delimitations :}

Delimitations of the study were:

- A group of technical middle school first graders at El Amal School for Deaf and Dumb in Benha.

- The following technological learning centers: Animation Center - Educational Film Center Educational Puzzles and Games Center - Knowledge Web Tours Center - stories.

- Creative thinking skills (fluency - flexibility originality).

- The environment unit prescribed for technical middle school first graders, first semester.

\section{Research Terms}

\section{Hard-of-hearing students}

They are students who have deficiencies in the sense of hearing, which reduces their ability to hear different sounds to varying degrees. Therefore, they need special educational programs that differ from those offered to ordinary people, so the materials consider their characteristics and needs and help them to acquire the skills necessary for them to learn and live.

\section{Creative thinking:}

It is a pattern of thinking in which the hearing impaired performs a set of mental processes that result in producing new and original things or giving new solutions to problems, dealing with issues in a more 
flexible way, predicting events, and giving the largest number of ideas, opinions or uses at a specific time.

\section{Technology learning centers}

They are corners of educational technology that are based on the use of systems, methods, tools, and technological means, which allow learners to practice many different activities through the availability of tools and materials to carry out these activities using multiple technology applications. Learners can move virtually from one center to another.

\section{Theoretical background:}

\section{First: Hearing Impairment:}

\section{Definition of hearing disability:}

Definitions of hearing impairment are varied.. Hassanein $(2013,41)$ defines hearing impairment as a deficiency in the auditory ability due to a problem somewhere in the auditory system, the problem may be in the outer, middle, or inner ear or in the auditory nerve connecting to the brain. Auditory impairment includes deaf and hard of hearing children.

Abu al-Nur and Muhammad $(2019,199)$ define it as the condition in which an individual suffers from auditory deficiency as a result of acquired genetic, congenital or environmental factors. It prevents him from learning and performing some social work and activities as performed by the ordinary individual. Auditory deficiency may be partial or total and includes children deaf and hard of hearing.

Consequently, the hearing impaired are individuals with a hearing impairment. It hinders them from 
performing their duties, which reduces their ability to hear different voices, and makes them need special educational and psychological services.

\section{Characteristics of the Hearing Impaired:}

Hearing impairment can profoundly affect a person in various aspects as follows: (Al-Khatib, 1998: 85; Touhami, 2006: 49, Popa \& Vanghelie, 2015: 338; Ljubica \& Tamara, 2015). The language of the hearing impaired is often characterized as not rich in vocabulary and meanings as the ordinary language.

- quickly forgetting information, Lack of concentration and difficulty recognizing abstract and symbolic stimuli.

- The tendency to be isolated and avoid others as a result of a feeling of inability to communicate.

- The tendency to avoid social interaction, isolation, and withdrawal positions.

Muhammad and Amer (2008: 195) argue that when educating the hearing impaired, attention should be paid to dealing with the active senses they have. Choosing short activities that do not take a long time, diversify and linking them to the environment. Attention to the use of visual aids.

\section{Science Curriculum for Hearing Impaired Prep Stage:}

Science subject is one of the most important subjects. It can sensitize all students, including the hearing impaired. It has a clear contribution to the education of learners with scientific knowledge and various skills. However, the science curricula currently offered to the hearing impaired in the technical middle school are 
characterized by their inadequacy and appropriateness to the nature of the hearing impaired in terms of their goals, content, teaching strategies and methods of evaluation. Consequently, these curricula failed to achieve the desired goals of teaching science to the hearing-impaired learners in the middle school (Ahmed, 2005).

Among the strategies and teaching approaches that the literature pointed to their effectiveness in teaching science for the hearing impaired, are individual education method, the environmental approach, learning through drama, the problem-solving method, "Hand, Brain Model, survey-based learning, Small Group Learning, Learning Centers, Play, Visual Aids Use, Thinking Maps, and School Activities (Muhammad 2002; Easterbrook \& Scheetz, 2004, 261; Mazen, 2012, 117; Patalano, 2015, 33; Issa, 2004)

Several previous studies and research have indicated the importance of using technology and its various applications in teaching science for the hearing impaired, such as Lemke (2002: 7), Lang \& Steely ( 2003), the Muhammad (2005), Sweet (2012), Attia (2012), Issa (2013), and Ibrahim (2013)

\section{Second: Creative thinking skills}

\section{Definition of creative thinking:}

Specialists in the field of education and psychology have provided several definitions of creative thinking.

Creative thinking is defined as a complex and purposeful mental activity guided by a strong desire to search for solutions or arrive at original results that 
were not previously known. It is comprehensive and complex. (Al-Qala, Nasser, and Jamal, 2006, 603)

It is also defined as a mental process in which the learner interacts with the many experiences he encounters and assimilates the elements of the situation in order to reach a new understanding or new production, achieving an original solution to his problem, or discovering something new that is valuable to him or the society in which he lives. (Al-Ayasrah, 2015,307 )

Ghanem $(2011,91)$ believes that creative thinking is to bring all-new, whether it is ideas, suggestions or even developing existing prevailing stereotypes or tools by issuing unfamiliar ideas or produce the largest number of ideas and opinions or produce the largest number of uses or applications.

Creative thinking skills and methods of their development

Creative thinking skills are as follows: (Mahmoud, $2006,95)$

1. Fluency: It means the ability to summon the largest possible number of appropriate responses to a specific problem or stimulus during a specific time period. Its components include fluency of forms, fluency of symbols or words, and fluency of meanings and ideas.

2. Flexibility: It means the learner's ability to change the state of mind by changing the situation, and to generate various responses.

3. Originality: It means the ability to produce novel, non-recurring ideas. 
4. Sensitivity to problems: it means noticing problems in the situation they are facing or in life situations.

5. Details: It means the learner's ability to add new things to a specific idea and reach complementary suggestions that lead to a new increase.

Methods that contribute to developing creative thinking skills are

Presenting topics as problems, brainstorming, roleplaying, cooperative learning, playing games, employing technology in the educational process, and projectbased learning, Creating an environment conducive to creative thinking free from limitations. (Issa, 2004; AlFiqi and Salem, 2008, 114; Muhammad, 2005, Daud, Omar, Turiman \& Osman, 2012) Among the methods that contribute to developing creative thinking skills are presenting topics in the form of problems, the method of brainstorming, role-playing and cooperative learning, playing and employing technology in the educational process, project-based learning, and creating an enabling environment for creative thinking free from restrictions. (Issa, 2004; Al-Fiqi and Salem, 2008, 114; Muhammad, 2005), Daud, Omar, Turiman \& Osman, 2012)

\section{Third: Technology learning centers}

Learning centers represent the areas or corners that are organized by the teacher in the classroom. It provides the materials and tools that learners need to practice activities inside. It includes a small number of learners (small groups). The activities that learners perform within these centers depend on exploration, 
and they allow learners to choose from different subjects and activities. It can be used in all educational levels. Examples of these centers include the Arts Center, the Library Center, the Cubes Center, the Computer Center, the Science Center, the Representative Play Center, the Music Center, and the Game Center (Kelly, 2001, 172; Bashir, 18, 2015; Shaalan and Nagy, 38, 2016; Judson, 2019, 250

The importance of learning centers is evident in their response to the pupils' different tendencies, responding to self-learning needs, providing opportunities for experimentation and testing, providing opportunities for students to take responsibility for achieving their comprehensive growth, and providing opportunities for exploration, experimentation and creativity (Al-Busat, 2015, 35, 2015; Aydogmuc \& Senturk, 2o19; Ballinger, 2011)

In the light of the foregoing, technology learning centers can be defined as a group of corners or virtual areas that are based on the use of technological methods, tools and programs in planning, implementing and evaluating the teaching and learning process. Examples include:

WebQuest, the Presentation Center, the Animation Center, and the Story Center (Electronic / Digital), And an electronic educational games center.

- WebQuest: In a WebQuest, the learner browses many electronic learning resources and delves into studying topics and conducting some survey activities. 
- Animation Center: This center is attractive and interesting; where the animation has the elements of color, sound, movement and image.

- Story Center: It includes a collection of digital or electronic stories, which may be real or imaginary. Through this center, sound and visual effects can be employed, which makes these stories more interesting and effective in achieving many of the goals of science education.

- Electronic educational games center: It includes a set of educational games and puzzles that require the learner to do many mental operations, and during play the learner gets the appropriate reinforcement and immediate feedback.

- The Educational Film Center: The learner watches educational films and performs some activities related to the events of the film at this center.

\section{Characteristics of technology learning centers:}

Technology learning centers are characterized by the following:

- All activities carried out by the learners inside the centers are presented through technological means and tools.

- Fixed centers, as learners can move, virtually, from one center to another.

- The learner receives the instructions of the center and he is evaluated electronically.

- Low costs, as it does not require equipping the centers with material tools as is the case in learning centers. 
Importance of technology learning centers for the hearing impaired:

Technology learning centers offer many opportunities for the hearing impaired. It is a good way to individualize education, as it considers individual differences and cognitive backgrounds. Information is presented in a variety of ways and methods and in an interesting way using different technological applications that address the sense of sight of the hearing impaired. It also contributes to a good understanding of abstract knowledge, experience and concepts, as well as providing multiple methods of evaluation and immediate review of student responses.

\section{Research hypothesis}

The research tried to validate the following hypothesis:

- There is a statistically significant difference at the 0.01 level between the mean scores of the research group in the pre and post measurements of the Torrance Creative Thinking Test (Figures - Image B) in favor of the post measurement.

\section{Research Procedures:}

- First: Reviewing the literature and previous studies that dealt with research variables.

- Second: Choosing the scientific content: The environment unit was chosen from the science curriculum for the first preparatory first year, the first semester of the academic year 2019-2020, and this unit was rebuilt electronically according to the following technology learning centers: Animation Center - Educational Film Center - Center for 
Educational Puzzles and Games - WebQuest Center Stories.

- Third: Preparing the student's guide according to the technology learning centers, which includes the unit's topics and objectives, the learning centers for each topic, and a schedule for following up the work inside the centers.

- Fourth: Preparing the teacher's guide according to the technological learning centers, to guide him in teaching the "environment" unit according to the technology learning centers to develop creative thinking skills. The guide included the concept of technological learning centers and how to use them, general instructions for the teacher, the general objectives of the unit, and the schedule for teaching Unit topics, group lessons for the unit and each lesson included instructional objectives and technology learning centers used. This guide was judged valid by a panel specialized jurors.

- Fifth: Research Instruments: The research tool was the "Torrance for Creative Thinking Photo (B)" test, translated by Muhammad Ahmad Mahmoud Khattab. This test was chosen to measure the creative thinking skills of students with hearing impairment in middle school because it is the most appropriate for the current research, so the response to it does not require the use of language skill. However, this test is characterized by high reliability coefficient.

Test description. The Torrance Photographer Test (B) consists of three activities: 
- The first activity (creating pictures): This activity includes a curved shape (in the form of a bean pill) with a brown color. The student must think of a picture of a subject that he can draw so that the curved shape is part of it and then give it a title. This activity measures the skill of originality and its duration is 10 minutes.

- The second activity (complementing the lines): This test consists of 10 incomplete shapes or missing lines. The student must complete these shapes so that he forms pictures no one else can think of. This activity measures the skill of originality, flexibility and fluency and its duration is 10 minutes.

- The third activity (the circles): This activity consists of 36 circles and the student should use these circles to draw a picture or shape by drawing inside or outside the circles or both together so that he forms the largest number of different images no one else thinks of. This test measures the skill of fluency, originality and flexibility and its duration is 10 minutes.

How to correct the test. The (fluency - flexibility originality) skills in the Torrance test (Figures B) are corrected as follows:

Test Stability: Several studies using the Torrance Picture (B) test for hearing impaired people have indicated that this test is characterized by high stability coefficients as shown in the following table.

It is clear from the previous table that all values of stability coefficients are at 0.01 level, which reflects that this test has a high degree of stability. 
Table (1) Scoring System of Torrance test for Figure B shapes

\begin{tabular}{|c|c|c|}
\hline Skill & Skill Activity & Skill Correction Method \\
\hline Fluency & $\begin{array}{c}\text { Activity } 2- \\
\text { Activity } 3\end{array}$ & $\begin{array}{l}\text { One mark on each drawing or onlv one shape, } \\
\text { and if a shape is repeated, then he does not take } \\
\text { a grade because he took a degree in the same } \\
\text { form before }\end{array}$ \\
\hline Flexibility & $\begin{array}{c}\text { Activity } 2- \\
\text { Activity } 3\end{array}$ & $\begin{array}{l}\text { One mark for each different form (I.e. responses } \\
\text { are in different categories). } \\
\text { Forms in one categorv take onlv one mark, } \\
\text { If the examinee drew a banana and the second } \\
\text { form is an apple and the third is a watermelon, } \\
\text { he takes one mark on the three shapes, because } \\
\text { these shapes fall into the fruits category. }\end{array}$ \\
\hline Originality & $\begin{array}{l}\text { Activitv } 1- \\
\text { Activity } 2- \\
\text { Activity } 3\end{array}$ & $\begin{array}{c}\text { The degree of originality ranges from (0-5) marks } \\
\text { divided as follows: } \\
\text { - If } 5 \% \text { of the research sample gives the same } \\
\text { response, the mark will be Zero because it is } \\
\text { considered common and has no originality or } \\
\text { creativitv. } \\
\text { - If } 4 \% \text { of the research sample gives the same } \\
\text { response, the mark will be (1). } \\
\text { - If } 3 \% \text { of the research sample gives the same } \\
\text { response, the mark will be (2) } \\
\text { If } 2 \% \text { of the research sample gives the same } \\
\text { response, the mark will be (3). } \\
\text { - If } 1 \% \text { of the research sample gives the same } \\
\text { response, the mark will be (4). } \\
\text { If the idea is new, uncommon, and innovative, } \\
\text { the examinee takes the full five grades. }\end{array}$ \\
\hline
\end{tabular}

Table (2) Torrance Test for Creative Thinking, Image B

\begin{tabular}{|c|c|c|}
\hline Study & Sample & Stability coefficients \\
\hline $\begin{array}{c}\text { Abdul Ghaffar } \\
(2000)\end{array}$ & (64) A deaf child & Ranging from (0.37 to 0.64 \\
\hline $\begin{array}{c}\text { Muhammad } \\
(2005)\end{array}$ & $\begin{array}{c}\text { A sample of the hearing } \\
\text { impaired }\end{array}$ & Ranging from (0,86-0,93) \\
\hline Al-Qatawi (2012) & $\begin{array}{c}\text { (50) pupils from the deaf and } \\
\text { hard of hearing }\end{array}$ & Ranging between (0.54-0.86) \\
\hline
\end{tabular}

Validity of the test:

The validity of the Torrance Picture (B) test was confirmed by reviewing several studies conducted in the Egyptian environment on deaf students, such as the study of Abdel Ghaffar (2000). The study of Mohamed (2005) and the study of Al-Qatawi (2012) verified the validity of this test. 
From the aforementioned, it is evident that many researchers have verified the validity and reliability of the Torrance test, so the researcher relied on the psychometric properties available in the Egyptian environment.

\section{Sixth: Implementing the research experiment:}

The implementation of the research experiment has passed through the following stages:

- The pre-application of the research tool, where the Torrance test of the image "B" shapes was applied to the research group before the beginning of teaching the unit to obtain the necessary Pre-grading for the statistical treatment of the research results.

- Teaching according to technology learning centers: The research group studied the environment unit according to technology learning centers.

- Post- administration of the study tool: After completing the application of the unit, the Torrance test of the image "B" forms was administered.

\section{Research results and their interpretation}

To answer the research questions and verify the validity of its hypothesis, which states that "there is a statistically significant difference at the 0.01 level between the mean scores of the research group in the pre and post measurements in the Torrance test for creative thinking (Figure B) in favor of postmeasurement", the search results were as follows:

First: Calculating the arithmetic mean and the standard deviation in the pre and post measurements of creative thinking skills included in the Torrance Creative 
Thinking test (Figures, Image B) and the overall score, as shown in Table (3)

Table (3): Arithmetic mean and standard deviation in the pre and post measurements of creative thinking skills included in the Torrance Creative Thinking test (Figures Picture B) and the overall score

\begin{tabular}{|c|c|c|c|c|c|}
\hline Skill & $\begin{array}{l}\text { App. } \\
\text { type }\end{array}$ & $\begin{array}{c}\text { MIN } \\
\text { degree }\end{array}$ & $\begin{array}{c}\text { Max. } \\
\text { degree }\end{array}$ & avg. & Std. Dev \\
\hline \multirow[t]{2}{*}{ Fluency } & Before & 8 & 12 & 10 & 1,604 \\
\hline & After & 19 & 24 & 21,75 & 1,669 \\
\hline \multirow{2}{*}{ Flexibility } & Before & 4 & 7 & 5,125 & 0,99 \\
\hline & After & 10 & 15 & 1,875 & 1,642 \\
\hline \multirow{2}{*}{ Originality } & Before & 20 & 26 & 22,25 & 2,315 \\
\hline & After & 36 & 44 & 39,375 & 2,924 \\
\hline \multirow{2}{*}{$\begin{array}{l}\text { Total score for creative } \\
\text { thinking skills }\end{array}$} & Before & 35 & 40 & 37,375 & 1,922 \\
\hline & After & 69 & 78 & 74 & 3,07 \\
\hline
\end{tabular}

Second: Using the Lucoxin test for the associated samples to calculate the significance of the differences between the averages of the study group ranks in the pre and post measurements, as shown in Table (4).

It is clear from the previous table that $\mathrm{z}$ values for significant differences between the pre and post measurements of creative thinking skills are significant at the 0.01 level.

These results prove the validity of the research hypothesis, which indicates the effectiveness of technology learning centers in developing creative thinking skills for the hearing impaired in technical middle school first graders.

\section{This result can be explained as follows:}

The improvement in fluency skill is mainly due to the fact that the activities students practiced inside technology learning centers required them to produce 
Table (4) value (z) for significant differences between the pre and post measurements of creative thinking skills "included in the Torrance Creative Thinking test Picture B" and the overall score using the Lucoxen test

\begin{tabular}{|c|c|c|c|c|c|c|}
\hline Skill & RNK & No & Mean & Total & Z- Val & $\begin{array}{c}\text { Significance } \\
\text { level }\end{array}$ \\
\hline \multirow{4}{*}{ Fluency } & Pos. ranks & 8 & 4,5 & 36 & \multirow{4}{*}{2,64} & \multirow{16}{*}{0,01} \\
\hline & $\begin{array}{l}\text { Neg. } \\
\text { ranks }\end{array}$ & 0 & 0 & 0 & & \\
\hline & Equal & 0 & & & & \\
\hline & Total & 8 & & & & \\
\hline \multirow{4}{*}{ Flexibility } & Pos. ranks & 8 & 4,5 & 36 & \multirow{4}{*}{2,56} & \\
\hline & $\begin{array}{l}\text { Neg. } \\
\text { rank }\end{array}$ & 0 & 0 & 0 & & \\
\hline & Equal & 0 & & & & \\
\hline & Total & 8 & & & & \\
\hline \multirow{4}{*}{ Originality } & Pos. rank & 8 & 4,5 & 36 & \multirow{4}{*}{2,53} & \\
\hline & $\begin{array}{l}\text { Neg. } \\
\text { rank }\end{array}$ & 0 & 0 & 0 & & \\
\hline & Equal & 0 & & & & \\
\hline & Total & 8 & & & & \\
\hline \multirow{4}{*}{ Total score } & Pos. ranks & 8 & 4,5 & 36 & \multirow{4}{*}{2,52} & \\
\hline & $\begin{array}{l}\text { Neg. } \\
\text { ranks }\end{array}$ & 0 & 0 & 0 & & \\
\hline & Equal & 0 & & & & \\
\hline & Total & 8 & & & & \\
\hline
\end{tabular}

the largest number of responses, whether written verbal responses or forms and pictures of stimuli related to the subject under study, in addition to the use of the global information network to collect images, which gave way to students to reach many responses and alternatives. The teamwork within the centers helped to benefit from and develop the other people's ideas.

- The improvement of the flexibility skill is mainly due to the activities carried out by students within technology learning centers. They allowed them to think about alternatives and possible solutions to 
solve problems. Preparing or completing stories in more than one way allowed students to think about alternative ideas.

- The improvement of the originality skill is mainly due to the fact that the activities carried out by students within technology learning centers sought to develop the skill of solving unconventional problems in innovative ways, visualize and develop ideas, and to convert innovative ideas into beneficial applications, which increased the opportunities for training students on the skill of originality.

\section{Research Recommendations:}

Considering the findings of the current research, we recommend the following:

- The need to use technology learning centers to develop many learning outcomes, such as developing or acquiring concepts, correcting alternative visualizations, and addressing learning difficulties in all stages of education.

- The necessity of going to prepare electronic courses for students at all educational levels, so that the content is enhanced with videos, pictures and various technological applications.

\section{Suggestions for Further Research}

Based on these results, additional research on the following topics will help to shape and enhance students' learning outcomes:

- The effectiveness of technology learning centers in developing some higher-order thinking skills among hearing-impaired students in middle school. 
- An electronic program in science based on technology learning centers to develop creative thinking skills for hearing impaired students in middle school.

\section{References}

\section{Arabic references}

- Abdul Ghaffar, Saad Abdul-Muttalib (2000). The capabilities and indicators of innovative thinking for deaf mute students from the first cycle of basic education, a development study. Unpublished PhD, Institute of Higher Studies for Childhood, Ain Shams University.

- Abdullah, Souad Fouad Ahmed (2017). The effectiveness of applying the play strategy in developing the creative thinking ability of hearing-impaired children in the kindergarten stage. Unpublished Master. Faculty of Education, Suez Canal University.

- Abu Al-Nour, Mohamed Abdel Tawab Moawad, and Mohamed, Amal Jumaa Abdel Fattah (2019). Teaching and learning strategies for people with special needs. Cairo: Dar Al Zahra

- Ahmed, Muhammad Rushdi Abu Shama (2005). A proposed approach in science for the hearing impaired in the light of the meaningful learning theory and its effectiveness in achieving some of the goals of science education. Unpublished PhD, Faculty of Education, Mansoura University.

- Al-Fiqi, Ismail Muhammad, and Salem, Ahmad Muhammad (2008). Teacher and development of thinking skills. Riyadh: AlRushd Library.

- Al-Qatawi, Sahar Mansour (2012). The effectiveness of a school activities program in developing creative thinking among a sample of hearing-impaired children. Educational and psychological studies, Journal of the Faculty of Education, Zagazig, 76, 72-116.

- Al-Tohamy, Hussein Ahmed Abdel Rahman (2006). Raising hearing impaired children in light of recent global trends. Cairo: The International Publishing House.

- Attia, Asmaa Mahmoud Mohamed Mahmoud (2012). The effectiveness of aprogram based on electronic games to develop achievement and innovative thinking among hearing impaired students in the first cycle of basic education. Unpublished Doctorate, Faculty of Graduate Studies in Education, Cairo University. 
- Ayasrah, Walid Tawfik (2015). Thinking Education Strategies and Skills, Oman:Osama House for Publishing and Distribution.

- Bashir, Hoda Ibrahim (2015). Educational environments in nurseries and kindergartens. Alexandria: Horus International Foundation.

- Easa, Sami Abdel Hamid Mohamed (2004). The effectiveness of a computer program in developing the ability to think creatively and professionally for the hearing impaired. Unpublished Master, College of Graduate Studies in Education, Cairo University.

- Ghanem, Muhammad Hassan (2011). Introduction to psychology of thinking. Cairo: Track.

- Hassanein, Awatef Mohamed Mohamed (2013). Raising and educating children with hearing disabilities in the twenty-first century. Cairo: Academic Library.

- Ibrahim, Rehab Abdel Moneim Bayoumi (2013). The effectiveness of a computer-based teaching program in developing thinking processes for hearing impaired children. Unpublished MA, Faculty of Education, Zagazig University.

- Issa, Nahed Al-Sayed Eid (2013). The effectiveness of a proposed curriculum based on interactive media in achieving some of the goals of science education for students with hearing impairment in middle school. Unpublished Master, College of Education, Damietta University.

- Khatib, Jamal (1998). Introduction to hearing disability. Jordan: Dar Al-Fikr Al-Arabi.

- Mahmoud, Salah El-Din Arafa (2006). Thinking Without Borders: Contemporary educational insights into teaching and learning thinking. Cairo: The World of Books.

- Mazen, Hussam Muhammad (2012). Educational curricula for people with special needs. Cairo: Academic Library.

- Mohamed, Mohamed Abdel-Ghani (2005). The effectiveness of using computers in teaching science to obtain and develop innovative thinking for the hearing impaired. Unpublished MA, Faculty of Education, Zagazig University.

- Mohamed, Rabie Abdel Raouf; Amer, Tariq Abdul Raouf (2008). Auditory disability. Cairo: Thebes Foundation for Publishing and Distribution.

- Mohamed, Refaat Mahmoud Bahgat (2002). The effectiveness of the entrance to learning centers in teaching science for hearing impaired students in the sixth grade of primary school. Journal of Research in Education and Psychology, Faculty of Education, Minia University, 16 (1), 1-40. 
- Qala, Fakhreddin; And Nasser, Younes; Camel, Muhammad Jihad (2006). General teaching methods in the information age. Al Ain: University Book House.

- Riyad, Hassan Muhammad Al-Aref (2000). The effectiveness of using the technological approach in teaching science to achieve academic achievement and develop the capabilities of innovative thinking and the acquisition of some science processes among primary school students. Future Insights for Educational Research, National Center for Educational Research and Development, 621-703.

- Rug, Amani (2015). Effective education and management of learning centers in kindergarten. Cairo: Modern Book House

- Shaalan, Mr. Muhammad, and Naji, Fatima Sami (2016). Learning centers in kindergarten. Cairo: Modern Book House.

- Sweet, Shaimaa Sabry Abdel Hamid (2012). Motives for using hearing impaired children in children's electronic magazines and their relationship to cognitive aspects. Unpublished Doctorate, Faculty of Education (Specific Departments), Banha University.

\section{Non-Arabic Reference}

- Aydogmus, M. , Senturk, C.(2019). The effects of learning stations technique on academic achievement: Ameta- analytic study. Research in Pedagogy, 9(1), 1-15

- Ballinger, D.M.(2011).Student attitudes toward the use of learning centers in the elementary general music classroom. The University of Utah.

- Daud, A. M., Omar, J., Turiman, P. \& Osman, K. (2012). Creativity in Science Education, Procedia - Social and Behavioral Sciences $, 59,467-474$.

- Easterbrooks, S. R. \& Scheetz, N. A. (2004). Applying critical thinking skills to character education and values clarification with students who are deaf or hard of hearing. American Annals of the Deaf, 149 (3) , 255-263.

- Flores,A. C. \& Rumjanek ,V.M. (2015). Teaching science to elementary school deaf children in Brazil . Creative Education, 6, 2127-2135.

- Judson, E. (2019). Learning stations in college classrooms. College Teaching, 67 (7), 250-251.

- Kelly, M.E.(2001). The primary program: Growing and learning in the heartland. Nebraska State Dept. of Education, Lincoln. Office of Children and Families., lowa State: Dept. of Education. 
- Lang, H. G. \& Steely, D. (2003). Web-based science instruction for deaf students : What research says to the teacher. Instructional Science, 31, 277-298.

- Lemake, C. (2002). enGauge $21^{\text {st }}$ century skills: Digital literacies for a digital age. North Central Regional Educational Laboratory: Naperville.

- Ljubica,I\& Tamara,K. (2015).Communication of the deaf and hard of hearing - The possibilities and limitations in education. TEME: Casopis za Drustvene Nauke, 39(4), 1495-1514.

- Patalano, F. I. (2015) . Science based education for students who are deaf and/ or Hard of hearing. published doctoral dissertation , Arcadia University.

- Pchenitchnaia, L.V. (2007).Essential and model programs for teaching and learning centers as reported by directors in selected research extensive universities :A Delphi study. Unpublished Doctoral, Texas A\&M University, United States.

- Popa, M. \& Vanghelie, M. L. (2015). Elements of experiential psychotherapy in the development of the social and emotional skills of the hearing impaired students. Procedia Social and Behavioral Sciences, 187, 338- 342.

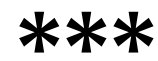

